Vietnam Journal of Mechanics, NCST of Vietnam Vol. 24, 2002, No $3(181-196)$

\title{
ON AN ONE- AND QUASI-TWO DIMENSIONAL LINKING HYDRAULIC MODEL FOR THE COMPLEX RIVER NETWORK-VALIDATION AND APPLICATION
}

\author{
Nguyen Van Hanh ${ }^{1}$, Ngo Huy Can ${ }^{2}$ and NguYen Van Diep ${ }^{2}$ \\ ${ }^{1}$ Institute for Water Resources Research, 271 Tay son street, Hanoi, Vietnam \\ ${ }^{2}$ Institute of Mechanics, 264 Doi can street, Hanoi, Vietnam
}

\begin{abstract}
This paper describes an approach to construct an one- and quasi-two dimensional hydraulic model for the complex river network, including various hydraulic structures. The model is based on the numerical solution of the Saint-Venant equations for river branches, the continuity equation for storages, the equation for junction conditions of the confluences, tributaries, the equation for hydraulic structures between rivers and storage cells. Cross sections are modeled as a combination of main and flood plain parts to simulate better the flow pattern. The calculating program has been developed, validated by test cases, proposed by European big hydraulic research laboratories and then applied to build a hydraulic model for the complicated Red-Thai Binh river network.
\end{abstract}

\section{Introduction}

Free surface flow in a river delta is complicated and is investigated extensively last years. The flow can be simulated by one- or two-dimensional mathematical models [1-3], depending on the study purpose. However, two-dimensional models are expensive for large river deltas. In this case, the main technique is to use an one- and quasi-two dimensional approach [3], which can be rather cheaper both in calculating time and cost.

In the one- and quasi-two dimensional approach the research area is considered as a combination of a river network and storage cells. Storage cells can exchange flow with rivers and with each other through hydraulic structures.

In this paper an approach to construct an one- and quasi-two dimensional linking hydraulic model for the complex river network is presented. The focus is an approach of verifying hydraulic program by various test cases to validate the numerical scheme.

The hydraulic model for the complex Red-Thai Binh river network is constructed, followed flood protection rules of the Government, including the special operational scheme of the Van Coc sluice and the Day dam. The model then is applied to evaluate flood scenarios.

\section{Equations}

For a general network there may exist a flow in river network, flow in- or outstorage cells. So one has to deal with three types of equations: partial differential 
equations for a single river branch, ordinary differential equations for storage cells and equations for hydraulic structures. Apart from these it is needed to add junction conditions in some location of the network to keep the flow continuity.

\section{Equations for a single river branch}

The free surface flow in a single branch of a river network can be described by the so-called Saint-Venant equations [1-3] under the assumption of a hydrostatic pressure and an uniform distribution of the velocity along the vertical axis.

In practice, the flow in the main channel and the flood plain are quite different due to different frictions. So the following type of equations are often used:

$$
\begin{aligned}
& \frac{\partial A_{s}}{\partial t}+\frac{\partial Q}{\partial x}=0, \\
& \frac{\partial Q}{\partial t}+\frac{\partial}{\partial x}\left(\frac{Q^{2}}{A_{f}}\right)+g A_{f} \frac{\partial Z}{\partial x}+g A_{f} \frac{Q|Q|}{K^{2}}=0,
\end{aligned}
$$

where

$Z$ is water elevation

$Q$ - discharge

$A_{s}$ and $A_{f}$ - wet cross sectional areas for the main and total flow

$K$ - conveyance

$g$ - gravity

$t$ - time

$x$ - space coordinate

Equations for storage cells

This is the continuity equation for storage cells

$$
\frac{d V}{d t}=\sum Q,
$$

where $V$ is the water volume, $Q$ is in- and out-going discharges.

\section{Equation for hydraulic structures and junction conditions}

The flow must be conservative, so at confluences or tributaries the sum of all discharges must be zero. At hydraulic structures flow rate is defined by the formula:

$$
Q=f\left(Z_{t l}, Z_{h l}, a\right),
$$

where $Z_{t l}, Z_{h l}$ are the upstream and downstream water levels and $a$ is characteristic parameter of structures. A structure may be modeled by one of two types: a spillway and a sluice. The discharge, going through a spillway is calculated by [4]

$$
\begin{aligned}
& Q=m b \sqrt{2 g}\left(Z_{t l}-Z_{0}\right)^{2} \text { for non- submerged flow } \\
& Q=\varphi b \sqrt{2 g}\left(Z_{h l}-Z_{0}\right) \sqrt{Z_{t l}-Z_{h l}} \text { for submerged flow }
\end{aligned}
$$


The discharge through sluices can be determined as follows:

$$
\begin{aligned}
& Q=\mu \omega \sqrt{2 g} \sqrt{Z_{t l}-Z_{0}} \text { for non- submerged flow } \\
& Q=\mu_{2} \omega \sqrt{2 g} \sqrt{Z_{t l}-Z_{h l}} \text { for submerged flow }
\end{aligned}
$$

where $m, \varphi, \mu, \mu_{2}$ are empirical coefficients for the structure; $b$ is the width of the spillway; $\omega$ is the wet area of the sluice, $g$ is the gravity, $Z_{0}$ is the sill level of the structure. Finally the initial and boundary conditions must be added.

\section{Method of solution}

To get numerical solutions the considered river network is split into river branches, separated by nodes. A node is a point in the river system where the Saint-Venant equations are not valid. A confluence or tributary or point of a literal discharge is a node. For a hydraulic structure in rivers it is associated with two nodes- upstream and downstream due to different water levels.

If the network consists of storage cells, that make the problem to be quasi-two dimensional, they are nodes also. Therefore structures that link rivers and storage cells have two nodes too.

The numerical method is based on the implicit 4-point Preissmann method [3] for river branches instead of high resolution numerical methods [5], implicit finite difference scheme for storage cells and linking discharges of hydraulic structures.

Nodes, branches, cross sections, hydraulic structures are numerated naturally from zero.

\subsection{Finite difference scheme for river branch's equations}

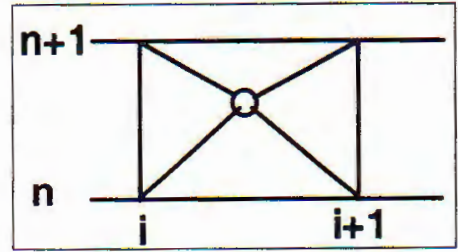

A branch with length $[a, b]$ is split so that:

$$
a=x_{k}<x_{k+1}<\cdots<x_{\ell}=b, \Delta x_{i}=x_{i+1}-x_{i}
$$

where $x_{i}(i=k, \ldots, \ell)$ are locations of cross sections. Using difference scheme for any function $f$ :

$$
\begin{aligned}
& \frac{\partial f}{\partial t}=\frac{1}{2}\left(\frac{f_{i}^{n+1}-f_{i}^{n}}{\Delta t}+\frac{f_{i+1}^{n+1}-f_{i+1}^{n}}{\Delta t}\right) \\
& \frac{\partial f}{\partial x}=(1-\theta)\left(\frac{f_{i+1}^{n}-f_{i}^{n}}{\Delta x_{i}}\right)+\theta\left(\frac{f_{i+1}^{n+1}-f_{i}^{n+1}}{\Delta x_{i}}\right),
\end{aligned}
$$

where $\theta$ is a time weight number, superscripts $n, n+1$ reffer to time steps. Using this from (2.1), (2.2) we can get algebraic equations for unknowns $Z$ and $Q$ :

$$
\frac{1}{2}\left[\frac{A_{s, i}^{n+1}-A_{s, i}^{n}}{\Delta t}+\frac{A_{s, i+1}^{n+1}-A_{s, i+1}^{n}}{\Delta t}\right]+\theta\left[\frac{Q_{i+1}^{n+1}-Q_{i}^{n+1}}{\Delta x_{i}}\right]+(1-\theta)\left[\frac{Q_{i+1}^{n}-Q_{i}^{n}}{\Delta x_{i}}\right]=0
$$




$$
\begin{aligned}
& \frac{1}{2}\left[\frac{Q_{i}^{n+1}-Q_{i}^{n}}{\Delta t}+\frac{Q_{i+1}^{n+1}-Q_{i+1}^{n}}{\Delta t}\right]+\theta\left[\frac{\frac{\left(Q_{i+1}^{n+1}\right)^{2}}{A_{f, i+1}^{n+1}}-\frac{\left(Q_{i}^{n+1}\right)^{2}}{A_{f, i}^{n+1}}}{\Delta x_{i}}\right]+(1-\theta)\left[\frac{\frac{\left(Q_{i+1}^{n}\right)^{2}}{A_{f, i+1}^{n}}-\frac{\left(Q_{i}^{n}\right)^{2}}{A_{f, i}^{n}}}{\Delta x_{i}}\right] \\
& +\frac{g}{2}\left[\theta\left(A_{f, i+1}^{n+1}+A_{f, i}^{n+1}\right)+(1-\theta)\left(A_{f, i+1}^{n}+A_{f, i}^{n}\right)\right]\left\{\theta\left[\frac{Z_{i+1}^{n+1}-Z_{i}^{n+1}}{\Delta x_{i}}\right]\right. \\
& \left.+(1-\theta)\left[\frac{Z_{i+1}^{n}-Z_{i}^{n}}{\Delta x_{i}}\right]\right\}+\frac{g}{2}\left\{\theta\left[A_{f, i+1}^{n+1} \frac{\left|Q_{i+1}^{n+1}\right| Q_{i+1}^{n+1}}{\left(K_{i+1}^{n+1}\right)^{2}}+A_{f, i}^{n+1} \frac{\left|Q_{i}^{n+1}\right| Q_{i}^{n+1}}{\left(K_{i}^{n+1}\right)^{2}}\right]\right. \\
& \left.+(1-\theta)\left[A_{f, i+1}^{n} \frac{\left|Q_{i+1}^{n}\right| Q_{i+1}^{n}}{\left(K_{i+1}^{n}\right)^{2}}+A_{f, i}^{n} \frac{\left|Q_{i}^{n}\right| Q_{i}^{n}}{\left(K_{i}^{n}\right)^{2}}\right]\right\}=0 .
\end{aligned}
$$

\subsection{Finite difference scheme for the storage equation}

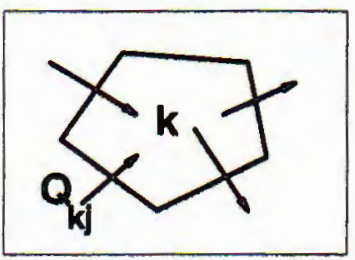

$$
\sum Q_{k j}^{n+1}-\frac{F_{k}^{n+1}}{\Delta t}\left(Z_{k}^{n+1}-Z_{k}^{n}\right)=0,
$$

for cell $k$ with water level $Z$, surface area $F \cdot Q_{k j}^{n+1}$ denotes the discharge between nodes $k$ and $j$.

\subsection{Finite difference scheme for the equation for structures}

For the structure with up- and downstream nodes $k$ and $\ell$ the finite difference scheme of equation (2.4) takes the form:

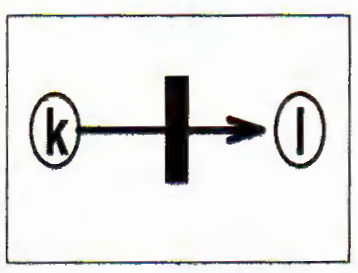

$$
\begin{aligned}
& Q_{k \ell}^{n+1}= Q_{k \ell}^{n}+\left.\frac{\partial f}{\partial Z_{k}}\right|_{Z_{k}=Z_{k}^{n}, Z_{\ell}=Z_{\ell}^{n}}\left(Z_{k}^{n+1}-Z_{k}^{n}\right) \\
& \quad+\left.\frac{\partial f}{\partial Z_{\ell}}\right|_{Z_{k}=Z_{k}^{n}, Z_{\ell}=Z_{\ell}^{n}}\left(Z_{\ell}^{n+1}-Z_{\ell}^{n}\right), \\
& Q_{\ell k}^{n+1}=-Q_{k \ell}^{n+1} .
\end{aligned}
$$

\subsection{Junction conditions}

At node $k$ which may be a confluence, a tributary, a literal point or an up- and down-stream of a structure:

$$
Z_{i}^{n+1}=Z_{j}^{n+1} \quad \sum_{i} Q_{k i}^{n+1}=0 .
$$

where $i, j$ are cross sections at ends of branches, linking with node $k$.

\subsection{Solution algorithm}

It is noticed that the number of equations at a node equals to the number of its branches. So together with boundary conditions that often are discharges at up-streams and water levels or discharge-water level relations at down-streams the 
number of unknowns is equal to the number of equations and is two times of the number of cross sections. Unknowns may be $Z^{n+1}, Q^{n+1}$ or $\Delta Z=Z^{n+1}-Z^{n}$, $\Delta Q=Q^{n+1}-Q^{n}$.

This algebraic system can be solved directly by the Newton method or by its linearized system with respect to point $\left(Z^{n}, Q^{n}\right)$. The program supports both options.

Mathematically, the system can be reduced to an another much smaller system of water levels at nodes. After solving this system, numerical solution for every branch is obtained by solving the system within the branch with water levels boundary conditions at two ends and calculating the discharges through structures. This technique reduces much time to solve the system.

The model also has following features:

- The arrangement of calculated sections in a river network can be defined by users. Cross sectional data are interpolated from data of measured sections.

- Reorganizing the input data when a river branch is divided into several smaller ones.

- Boundary conditions are given in the form of discrete non-equal time series. The calculated time interval should be inside time intervals of all boundaries.

\section{Test cases}

Verifying the numerical scheme is an important step in constructing models. Let us consider 3 groups of test cases [6,7]: analytical solutions, various wave types, network components. The first group is used to evaluate the model by analytical solutions. The second group- by simulating dynamic, diffusion and flood wave through large reservoirs. The third group is used to evaluate the model in various topographical data.

\subsection{Analytical solutions}

Case 1: Released wave in a rectangular channel

Let us consider an uniform flow with velocity $U_{0}$ and water depth $H_{0}$ in a rectangular channel branch. The channel slope is zero and the friction is neglected. The velocity at the upstream boundary is linearly reducing to zero after time $T$. This causes a wave, in which at each time moment the water level and discharge are reduced in the direction of reducing $x$ (see Fig. 1).

The calculation result with $U(0, t)=U_{0}\left(1-t / T_{\max }\right) \mathrm{m} / \mathrm{s}, \quad H=H_{0}=5 \mathrm{~m}$, $T_{\max }=1000 \mathrm{~s}, U_{0}=2 \mathrm{~m} / \mathrm{s}$ shows that the water level error at the upstream is less than $0.002 \mathrm{~m}$ and the water surface error at last moment - less than $0.13 \mathrm{~m}$. These show that the numerical solution approximates to the analytical one. A comparison between analytical and calculated solutions is illustrated in figure 1.

Case 2: Steady sub-critical flow in a rectangular channel branch

It is used to evaluate the numerical scheme with respect to gradient and friction terms in the steady state. The analytical solution is considered as the numerical solution, getting from the Runge-Kutta method, for the following equation: 


$$
\frac{d H}{d x}=\frac{1-\frac{q^{2}}{k^{2} R^{2} H^{4 / 3}}}{1-\frac{q^{2}}{g H^{3}}}=\frac{1-\frac{q^{2}}{k^{2} H^{10 / 3}}}{1-\frac{q^{2}}{g H^{3}}} ; \quad q=\frac{Q}{B}
$$

where $H$ is the water depth, $Q$ - the discharge, $q$ - the unit discharge, $k$ - the strickler coeffient, $R$ - the hydraulic radius, $B$ - the width, $I$ - the bed slope and $g$ - the gravity.

The calculation is carried out for two cases: $Q_{u p}=1000 \mathrm{~m}^{3} / \mathrm{s}, H_{\text {down }}=7 \mathrm{~m}$ and $H_{\text {down }}=3 \mathrm{~m}$ with different space increments $\Delta x=1000 \mathrm{~m}$ and $\Delta x=100 \mathrm{~m}$ for a channel branch with length $18000 \mathrm{~m}$.

The water level error (less than $0.001 \mathrm{~m}$ ) shows that the presented numerical scheme is appropriate. The result is shown in figure 2.

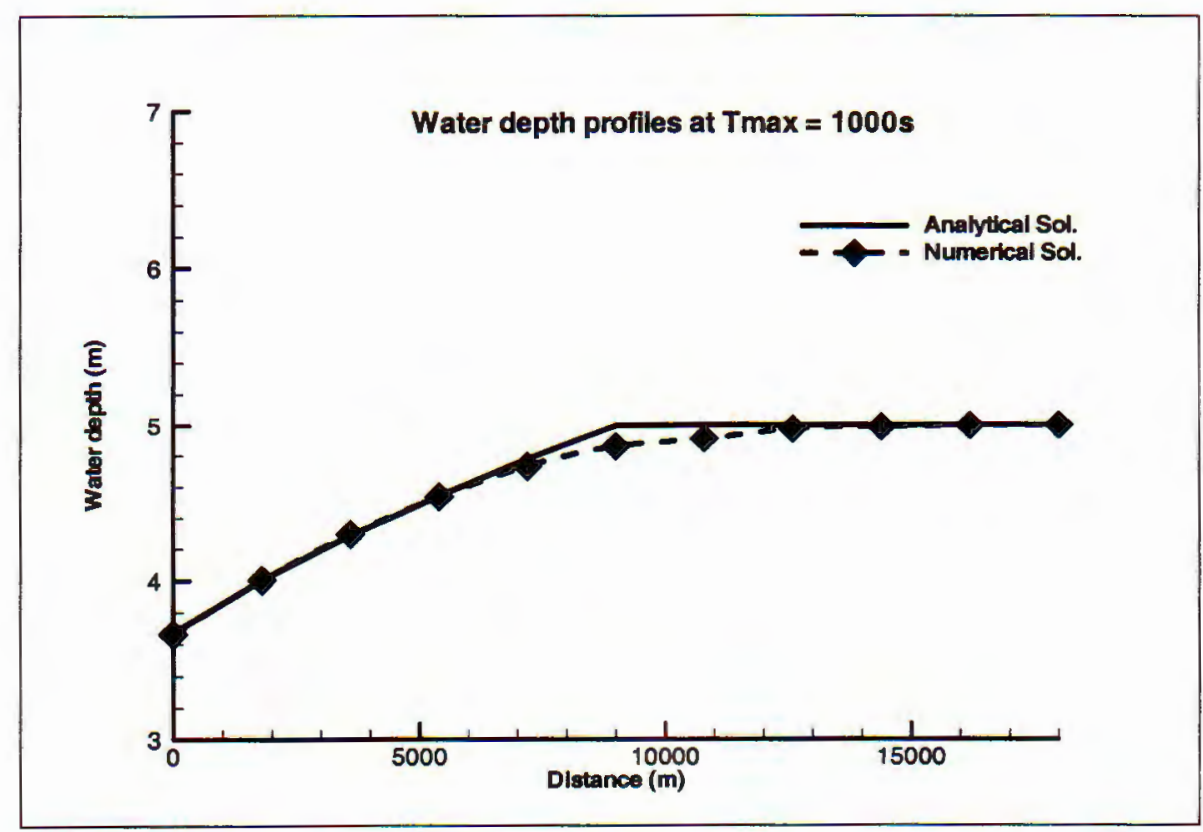

Fig. 1. Water profiles for the released wave. $\Delta x=100 \mathrm{~m}$

Case 3: Steady flow in a network with literal discharges

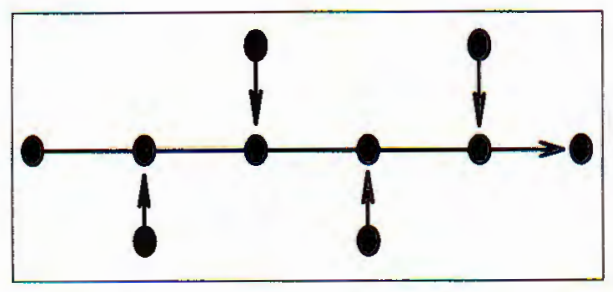

This test is used to verify the numerical scheme for processing with literal discharges. Channel network consists of 5 rivers. The main river has $5000 \mathrm{~m}$ length. Four other rivers has $1000 \mathrm{~m}$ length, $10 \mathrm{~m}$ width and are located at distances $1000 \mathrm{~m}, 2000 \mathrm{~m}, 3000 \mathrm{~m}$, $4000 \mathrm{~m}$ along the main river. The flow is steady and sub-critical. 
The calculation is done for 2 options: the option of a network with 5 rivers and the option of a main river with 4 literal discharges that are equal to the boundaries of sub-channels. The numerical solution for the first option is nearly as the same as the analytical one. The error for the second option is less than $0.02 \mathrm{~m}$. Therefore the model can simulate well network with literal discharges.

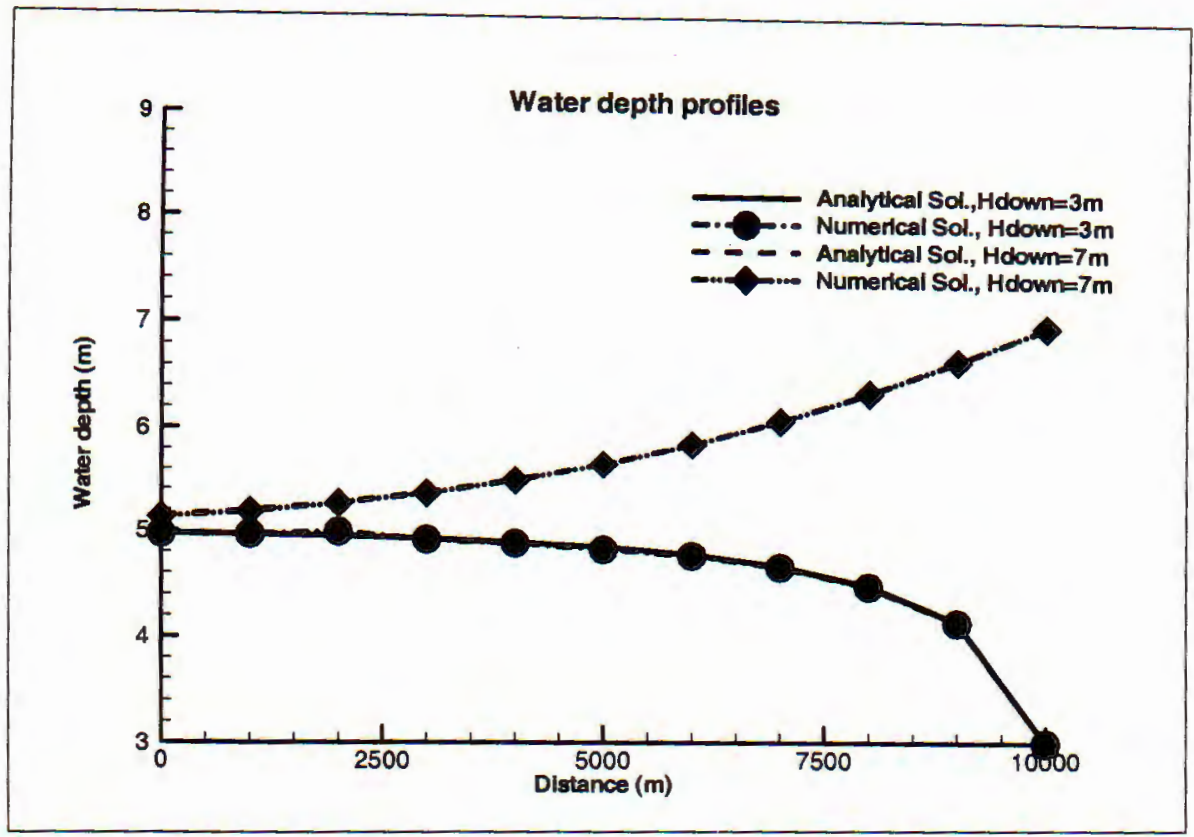

Fig. 2. Water depth profiles for steady sub-critical flow in a rectangular channel. $\Delta x=1000 \mathrm{~m}$

Case 4: Steady flow through a structure

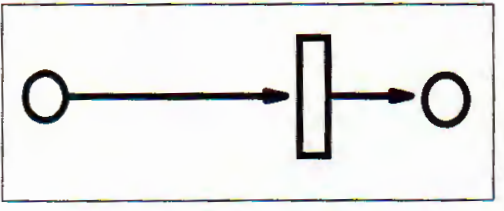

Let us consider the steady flow with discharge $Q=1000 \mathrm{~m}^{3} / \mathrm{s}$ in a rectangular channel of the $5000 \mathrm{~m}$ length. A structure is located at distance from 4000 to $4100 \mathrm{~m}$ with the discharge law $Q=100\left(H-H_{s}\right)^{3 / 2}$, where $H$ is the upstream water level and $H_{s}$ is the sill level of the structure. The downstream depth is $3 \mathrm{~m}$.

The water level error before and after the structure is $0.0001 \mathrm{~m}$ and 0 . This shows that the model can simulate the flow through structures well. The flow pattern is shown in figure 3.

\subsection{Various wave types}

Case 1: Dynamic wave

This test is used to verify the numerical scheme and sensibility of time steps with respect to propagation of the dynamic wave where the acceleration term is dominated. The wave is shown in the figure with $Q_{\max }=2000 \mathrm{~m}^{3} / \mathrm{s}, Q_{0}=1000 \mathrm{~m}^{3} / \mathrm{s}, T=30 \mathrm{~s}$.

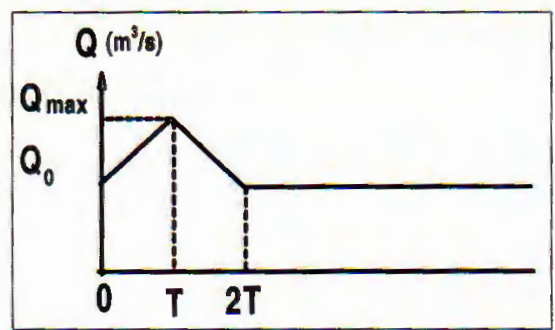


It propagates in a horizontal rectangular channel without friction. The result is illustrated at locations $x=0,4000,8000,12000 \mathrm{~m}$. From figure 4 it can be seen that the wave is simulated well enough with respect to the flow pattern in comparision with the results presented in $[6,7]$.

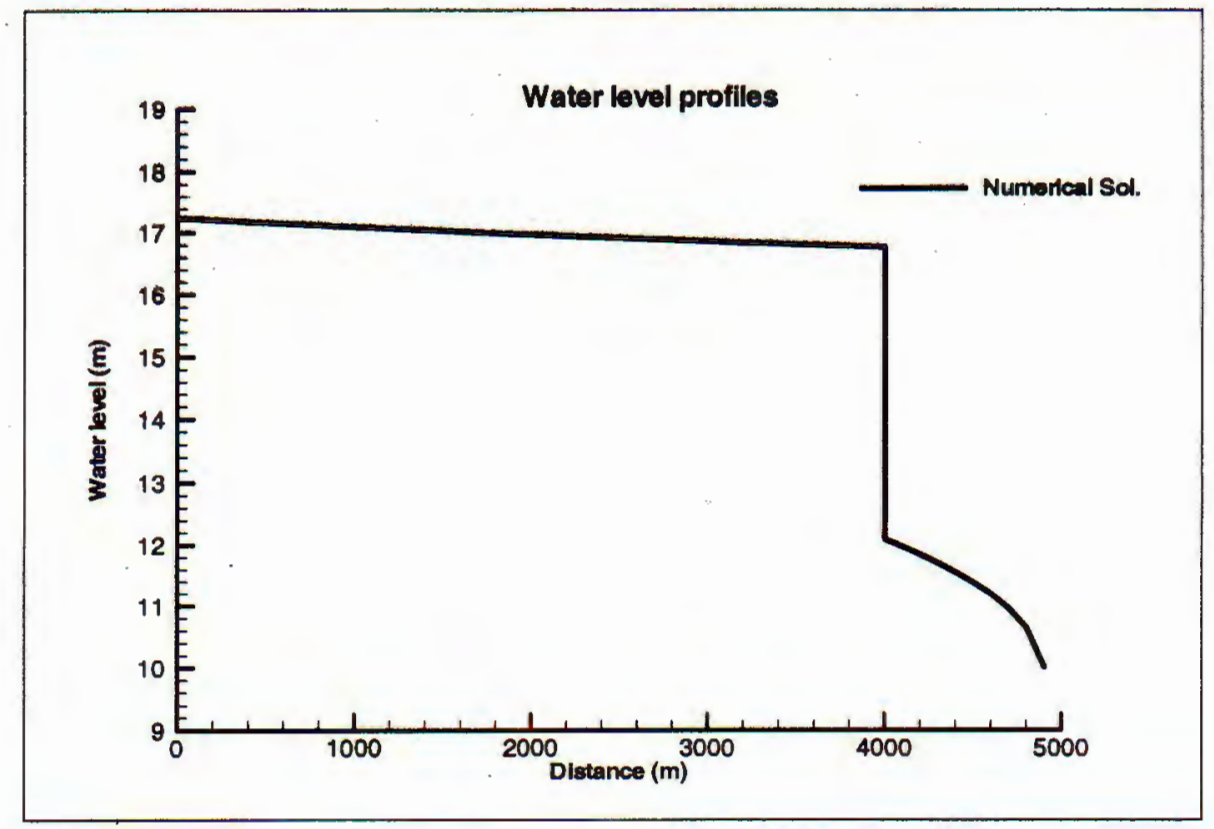

Fig. 3. Steady flow through a structure. $\Delta x=100 \mathrm{~m}$

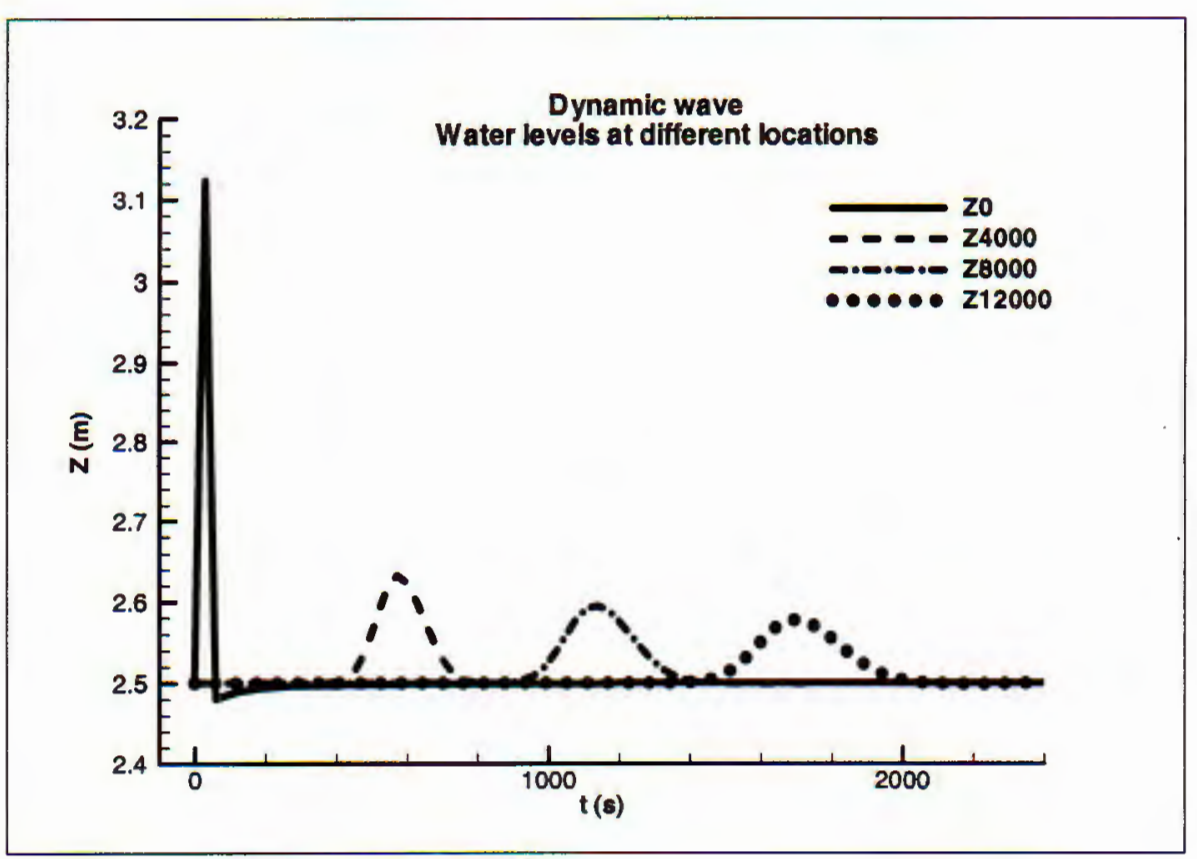

Fig. 4. Dynamic wave at different locations. $\Delta x=100 \mathrm{~m}$ 


\section{Case 2: Diffusion wave}

This is a long wave where the acceleration is small with respect to the other terms. The channel is rectangular with length $L=50000 \mathrm{~m}$, slope $I=0.0005$, Strickler coefficient $k=35$.

The wave has the same form as in the Case 1 with $Q_{\max }=2000 \mathrm{~m}^{3} / \mathrm{s}, Q_{0}=$ $750 \mathrm{~m}^{3} / \mathrm{s}, T=1800 \mathrm{~s}$.

The calculation is done for the $900 \mathrm{~s}$ time increment and the $1000 \mathrm{~m}$ space increment.

The result drawn for locations $x=0$ and $x=25000$ is presented in figure 5 . It shows that the flow pattern is acceptable in comparison with the results presented in $[6,7]$.

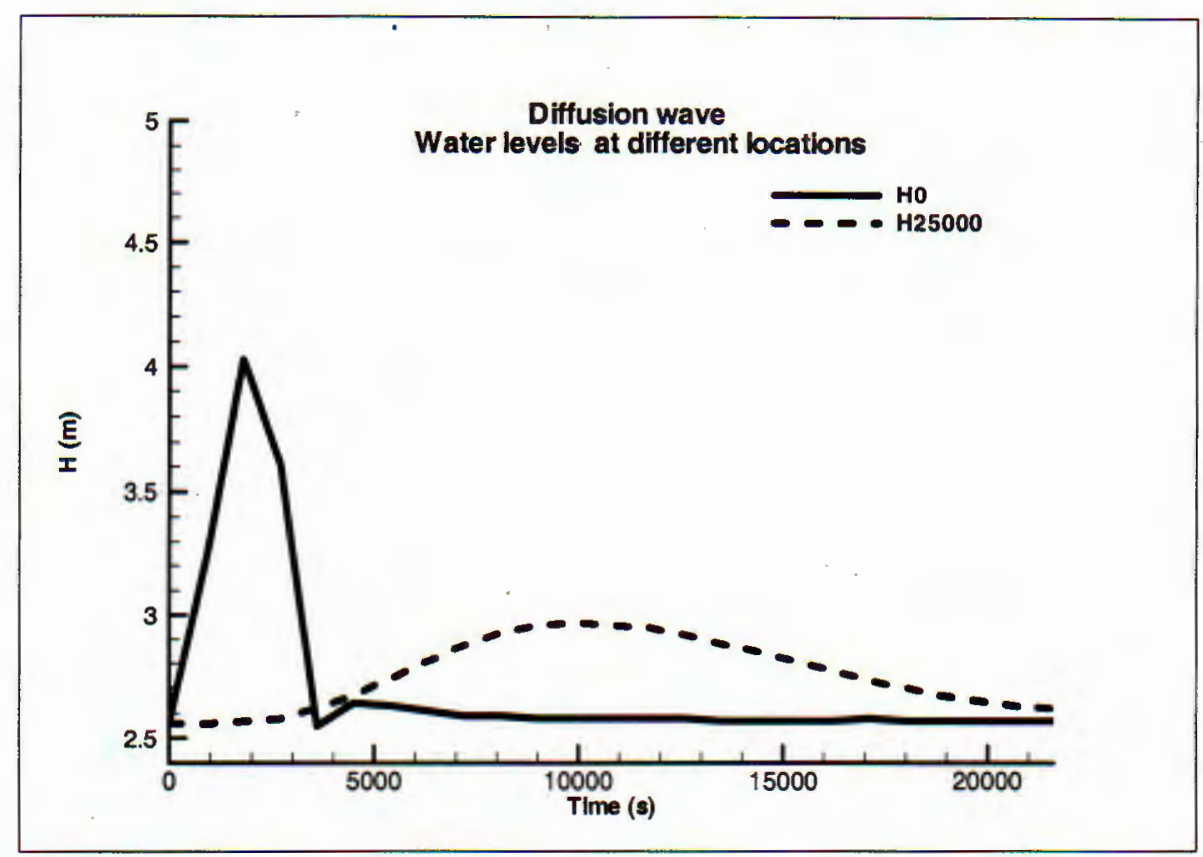

Fig. 5. Diffusion wave, $\Delta x=1000 \mathrm{~m}$

\section{Case 3: Wave through a large reservoir}

This test is used to verify the numerical model for the case of a wave through a large reservoir. The storage is rectangular with length $L=4000 \mathrm{~m}$, width $B=$ $1000 \mathrm{~m}$. Its bed is horizontal with no friction. At the up stream boundary there is a long way with period 24 hours. At the down stream the discharge-water level relation is given.

The calculation is carried out for two cases: $\Delta t=300 \mathrm{~s}, \Delta x=100 \mathrm{~m}$ and $\Delta t=1800 \mathrm{~s}, \Delta x=100 \mathrm{~m}$.

The result shows that in comparison with the analytical solution presented in $[6,7]$, the model has the ability to simulate this wave. The flow pattern is shown in figure 6 . 


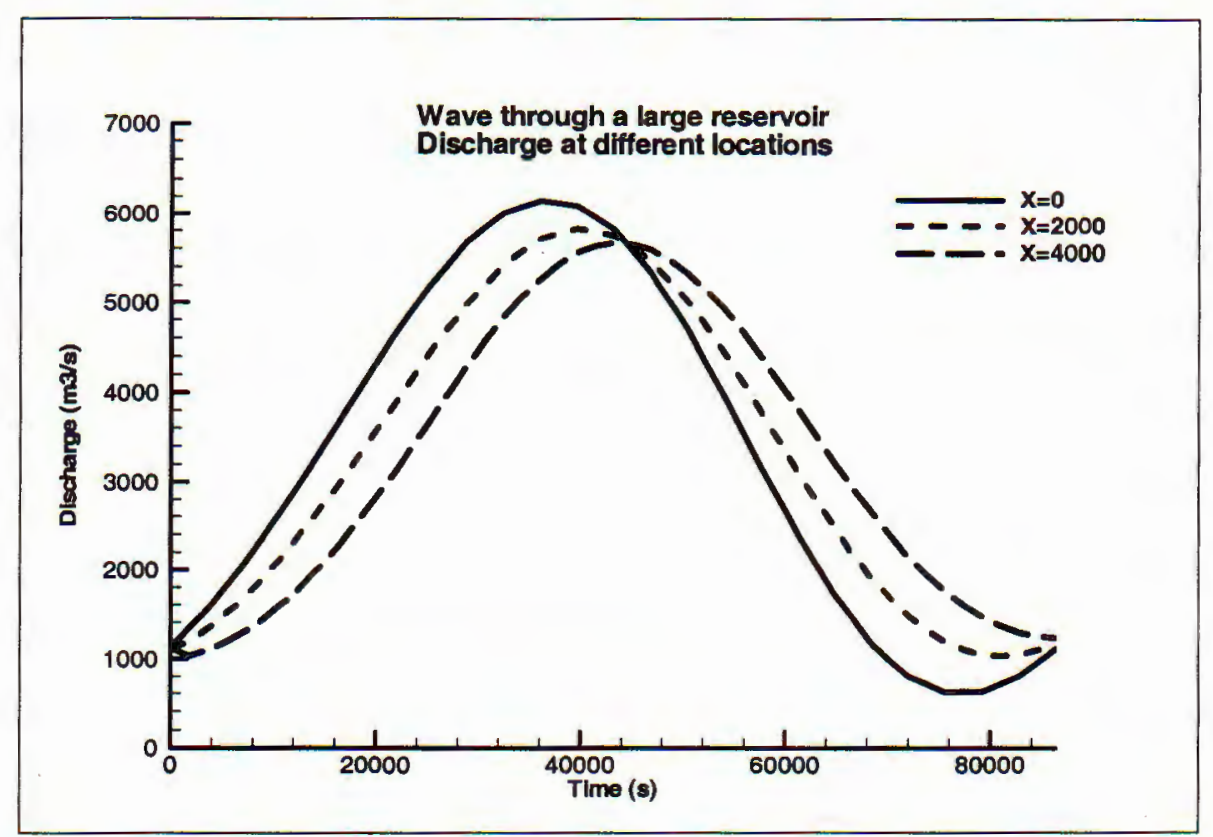

Fig. 6. Discharges. $\Delta x=40 \mathrm{~m}$

\subsection{Network components}

\section{Case 1: Local disturbances}

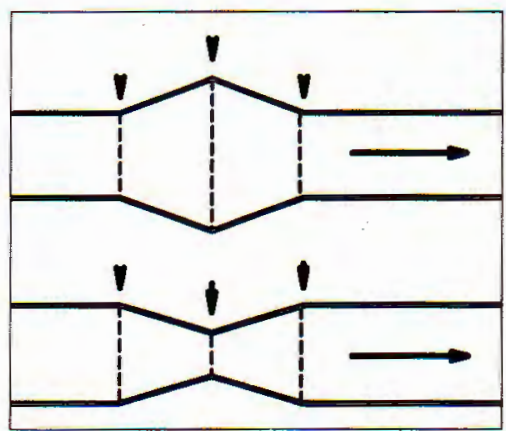

This test is used to verify the model in simulating flow near local topographical changes. The channel is rectangular with constant slope 0.0001 and constant width $B=100 \mathrm{~m}$. For the cases of increasing and reducing width $B$ is equal to $200 \mathrm{~m}$ and $50 \mathrm{~m}$. The flow is steady with $Q=1000 \mathrm{~m}^{3} / \mathrm{s}$ and downstream depth $H=5 \mathrm{~m}$.

The results show that the water level is higher at the wider cross section and is lower at the narrower cross section. That is a correct flow pattern. Figure 7 illustrates the result for the narrower cross section case.

\section{Case 2: Steady flow for non-uniform geometry}

This test is used to verify the flow pattern in the non-uniform geometry. The calculation is carried out for two cases: (a) linear change of the cross section (increasing or reducing) with constant Strickler coefficient and (b) linear change of Strickler coefficient with constant cross section. The maximum changes occur at the middle of the channel. Cross sections are trapezoidal. 


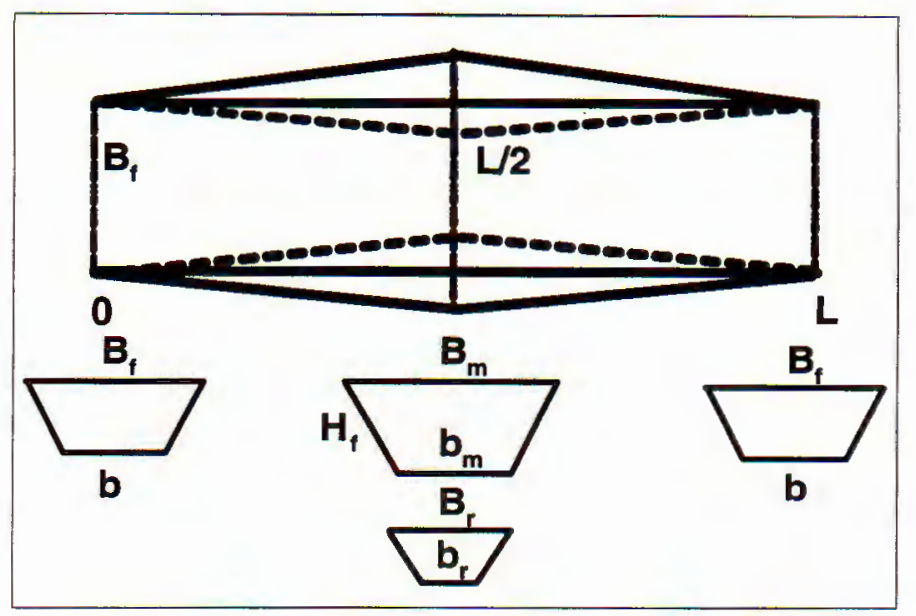

The obtained numerical results show the correctness of numerical solutions. The expanding cross sections has the same effect as increasing Strickler coefficients and the reducing cross section has the same effect as reducing Strickler coefficients. The result for the reduced cross section and Strickler coefficient is illustrated in figure 8 .

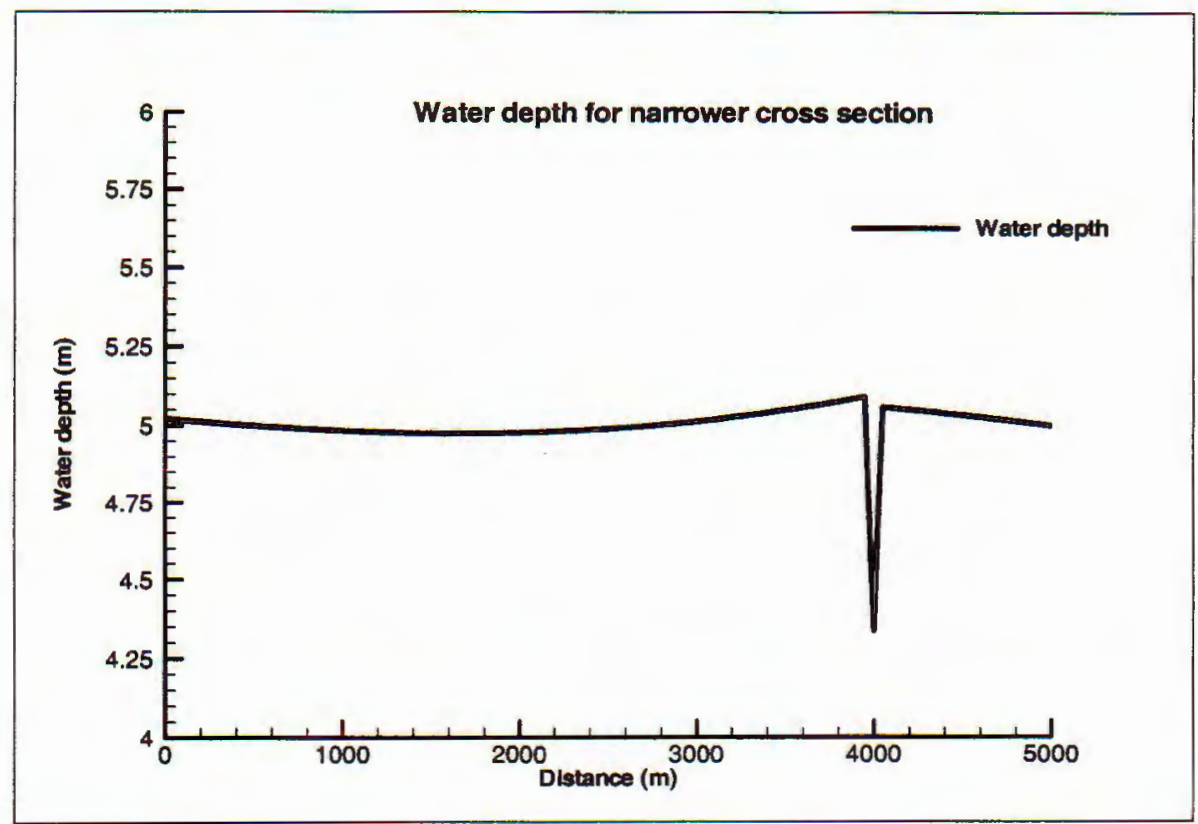

Fig. 7. Depth profile, $\Delta x=50 \mathrm{~m}$

Case 4: Tributaries

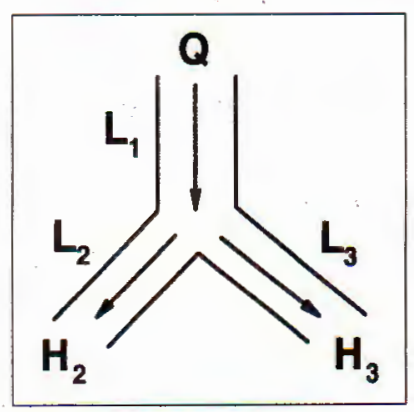

This test is used to verify the distribution of discharges at tributaries. The network consists of 3 river branches that are linked by one tributary as shown in the figure on the left.

The calculation is carried out for 5 cases with change of different flow conditions: upstream discharge, downstream water level, cross section.

The conclusion is that the total discharge is always equal to the sum of tributắry discharges. 


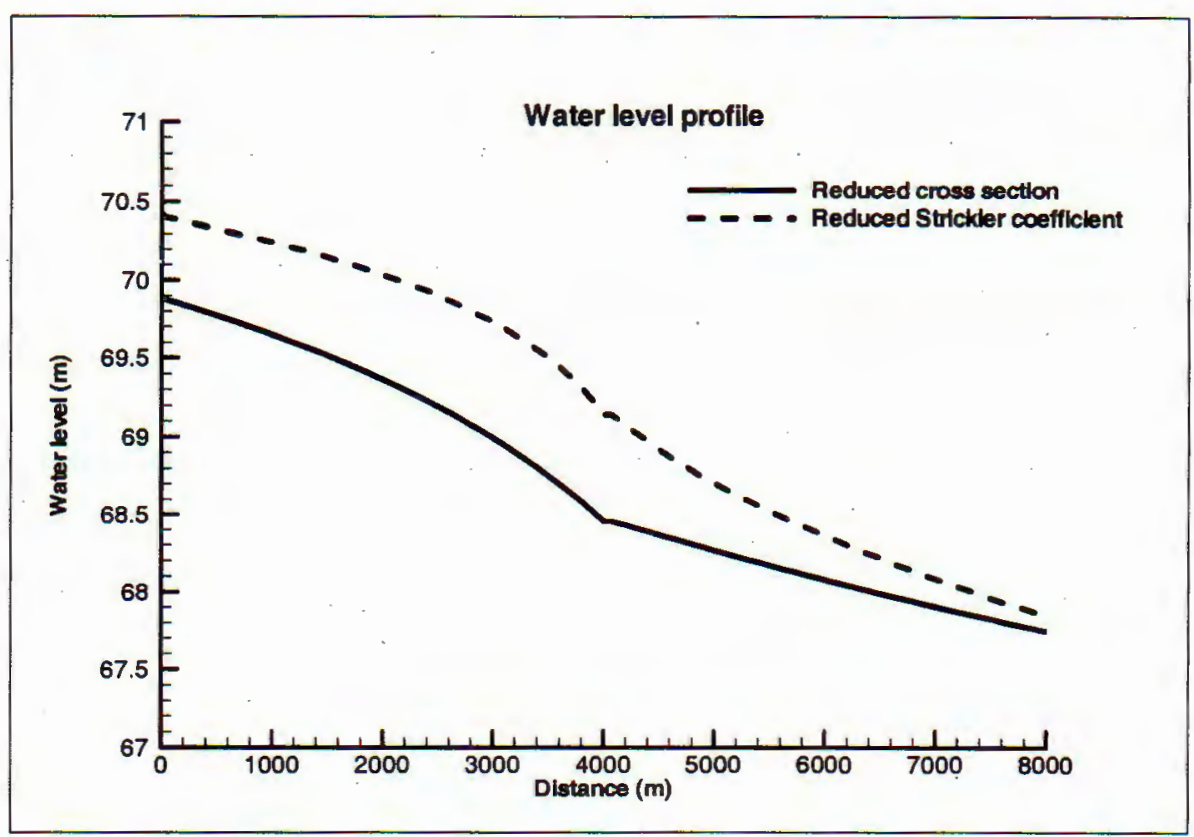

Fig. 8. Water levels for reduced cross section and Strickler coefficient

\section{Application to the Red-Thai Binh river network}

In this part the application of the model to the Red-Thai Binh river network is presented. This model is constructed to adapt the existing flood protection rules: (1) Simulating flood in river network, (2) Simulating flood into Day river through flood diversion structures of the Van Coc sluice and the Day dam when the water level at Hanoi is above $13.6 \mathrm{~m}$, (3) Simulating flood into retention area if the flood diversion does not reduce the water level at Hanoi bellow $13.6 \mathrm{~m}$.

The calculation network is shown in Figure 9. It is quasi-two dimensional and consists of a river network, flood diversion areas in the Day river catchment, retention areas Tam Thanh, Lap Thach, Luong Phu, Vinh Tuong.

Discharge boundaries of the network are given at stations: Hoa Binh on the Da river, Yen Bai on the Thao River, Thac Ba on the Chay river, Tuyen Quang on the Lo river, Lien Son on the Pho Day river, Phu Cuong on the Ca. Lo river, Thac Huong on the Cau river, Cau Son on the Thuong river, Chu on the Luc Nam river, Chi Thuy on the Tich river and Hoang Long on the Hung Thi river. Water level boundaries are given on 9 estuaries: Day, Ninh Co, Ba Lat, Tra Ly, Thai Binh, Van Uc, Lach Tray, Cam, Da Bach.

The topographical data are measured in period 1999-2000 years.

For the Red-Thai Binh river network special treatments are needed to simulate flow through the Van Coc sluice and the Day dam because of their special operational rules. The Van Coc sluice is a structure linking the Red river and the Van Coc lake. The Day dam is a structure linking the Van Coc reservoir and the Day river. These 
structures are closed most of time. In flood seasons, when the water level at Hanoi is rising above $13.6 \mathrm{~m}$ the Van Coc sluice begins opening to let water flow into the Van Coc reservoir. When the difference of water level at up- and down- streams of the Day dam is more than $6 \mathrm{~m}$ the Day dam starts to open. Its wall level is reducing from elevation 13.9 to $12.9,11.7,10.35,9 \mathrm{~m}$ in nearly 11 hours with the equal lowering and rest period of 1 hour and 15 minutes.

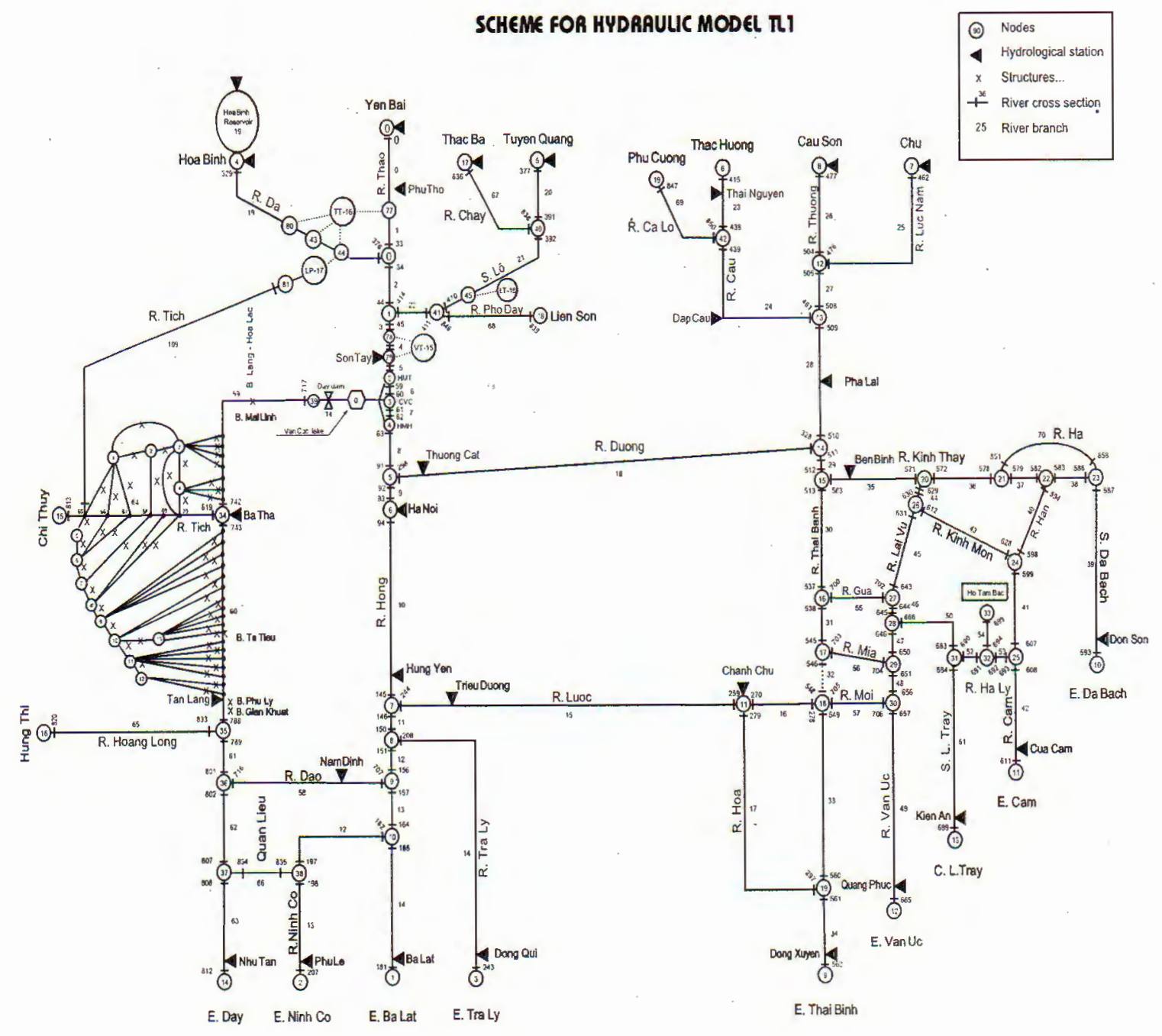

Fig. 9. Scheme for hydraulic model

To catch the short opening process of the Van Coc sluice and lowering process of the Day dam the model can change the time step smaller at the moment of opening sluice Van Coc.

The model is calibrated for the flood in 1996 and then is verified in 1999, 2000 
years. The error for several main stations such as Son Tay, Ha Noi, Thuong Cat, Pha Lai ... is less than $20 \mathrm{~cm}[8-9]$.

The model has been used for experimental evaluation of flood reducing effects of different flood control measures in the Red-Thai Binh river system.

For the 125-year flood (like the 1971 year flood) the effect of the Hoa Binh reservoir is considered in 3 flood forms [10]: 1969, 1971, 1996. The result is shown in the table 1:

Table 1. Water levels for the 125 - year flood

\begin{tabular}{|c|c|c|c|c|c|c|}
\hline \multirow[b]{2}{*}{$\begin{array}{c}\text { Maximum } \\
\text { of values }\end{array}$} & \multicolumn{2}{|c|}{1969 form } & \multicolumn{2}{|c|}{1971 form } & \multicolumn{2}{|c|}{1996 form } \\
\hline & $\begin{array}{l}\text { No Flood } \\
\text { control } \\
\text { measure } \\
\text { of } \mathrm{H} \text {. Binh } \\
\text { reservoir }\end{array}$ & $\begin{array}{l}\text { With } \\
\text { effect of } \\
\text { Hoa Binh } \\
\text { reservoir }\end{array}$ & $\begin{array}{l}\text { No Flood } \\
\text { control } \\
\text { measure } \\
\text { of } \mathrm{H} \text {. Binh } \\
\text { reservoir }\end{array}$ & $\begin{array}{l}\text { With } \\
\text { effect of } \\
\text { Hoa Binh } \\
\text { reservoir }\end{array}$ & $\begin{array}{l}\text { No Flood } \\
\text { control } \\
\text { measure } \\
\text { of } \mathrm{H} \text {. Binh } \\
\text { reservoir }\end{array}$ & $\begin{array}{l}\text { With } \\
\text { effect of } \\
\text { Hoa Binh } \\
\text { reservoir }\end{array}$ \\
\hline$Q_{\text {Sontay }}$ & 39216 & 28020 & 39900 & 27827 & 38770 & 27035 \\
\hline$Z_{\text {Sontay }}$ & 17.39 & 16.04 & 17.47 & 16.03 & 17.37 & 15.94 \\
\hline$Q_{\text {Hanoi }}$ & 31754 & 21964 & 32298 & 21838 & 31558 & 21145 \\
\hline$Z_{\text {Hanoi }}$ & 14.61 & 13.42 & 14.65 & 13.41 & 14.60 & 13.30 \\
\hline$\underbrace{Z_{\text {HoaBinh }}}_{\text {dam }}$ & \multicolumn{2}{|c|}{115.13} & \multicolumn{2}{|c|}{115.58} & \multicolumn{2}{|c|}{115.51} \\
\hline
\end{tabular}

This shows that for the 125-year flood it is enough to use the Hoa binh reservoir for flood protection. The water level at $\mathrm{Ha}$ Noi does not rise above $13.60 \mathrm{~m}$.

For the 500-year the effect of the Hoa Binh reservoir and flood diversion and retention are considered in 3 flood forms [10]: 1969, 1971, 1996. The result for the 1971-year flood form is shown in table 2.

This shows that for the 500-year flood it is necessary to operate all flood protection structures such as the Hoa binh reservoir, flood diversion in the Day river and flood retention into Tamthanh, Lapthach, Luongphu areas to ensure that the water level at Hanoi will be less than $14 \mathrm{~m}$ (less than dyke levels).

\section{Conclusions}

It is presented some results in developing linked one-dimensional and quasi-two dimensional hydraulic model based on the using implicit 4-points Preissmann finite difference scheme for river branches, implicit scheme for storage cells and linking discharge through hydraulic structures to study flood problems in the Red-Thai Binh river system. 
Table 2. Water levels for the 500-year flood

\begin{tabular}{|c|c|c|c|c|}
\hline $\begin{array}{l}\text { Maximum } \\
\text { of values }\end{array}$ & $\begin{array}{l}\text { No flood control } \\
\text { measure of Hoa } \\
\text { Binh reservoir }\end{array}$ & $\begin{array}{l}\text { With effect of } \\
\text { Hoa Binh } \\
\text { reservoir }(\mathrm{A})\end{array}$ & $\begin{array}{c}(\mathrm{A})+\text { Flood } \\
\text { diversion }(\mathrm{B})\end{array}$ & $\begin{array}{c}(\mathrm{A})+(\mathrm{B})+\text { Flood } \\
\text { retention }\end{array}$ \\
\hline$Q_{\text {Sontay }}$ & 50071 & 37261 & 36606 & 36481 \\
\hline$Z_{\text {Sontay }}$ & 18.76 & 17.13 & 16.67 & 16.65 \\
\hline$Q_{\text {Hanoi }}$ & 40928 & 29966 & 25921 & 25841 \\
\hline$Z_{\text {Hanoi }}$ & 15.62 & 14.41 & 13.94 & 13.92 \\
\hline$Z_{\mathrm{Van} C \mathrm{coc}}$ & & & 14.95 & 14.82 \\
\hline$Q_{\text {Day dam }}$ & & & 3960 & 3840 \\
\hline$Z_{\text {Tamthanh }}$ & & & 19.69 & 20.79 \\
\hline$Z_{\text {Lapthach }}$ & & & 14.82 & 18.40 \\
\hline$Z_{\text {Luongphu }}$ & & & 14.75 & 17.44 \\
\hline$Z_{\text {Hoabinh }}$ & & 114.45 & & \\
\hline
\end{tabular}

First of all the model has been validated by test cases developed and used in European hydraulic research laboratories.

After validation, the model has been calibrated by using historical collected data in the 1996, 1999, 2000 years. Finally the model is used for experimental evaluation of flood reducing effects of different flood control measures in the Red-Thai Binh river system.

This publication is completed with financial support from the research project on flood control in the Red-Thai Binh river system, Ministry of Agriculture and Rural Development, and from the National Basic Research Program in Natural Sciences, Ministry of Science, Technology and Environment.

\section{REFERENCES}

1. K. Inoue. Numerical analysis of overland flood flows by means of one- and twodimensional models, The $5^{\text {th }}$ JSPS-VCC Seminar on integrated engineering 'Engineering Achievement and Challenges' 1994, p 388-397.

2. S. Guillou and K. D. Nguyen. An improved technique for solving two-dimensional shallow water problems, Intern. J. for Numerical Methods in Fluids, 29, 1999, 465-483.

3. Cunge J. A., Holly F. M., Verwey A. Practical Aspects of Computational River Hydraulics, Pitman Advanced Publishing Program, Poston,London, Melbourne, 1980. 
4. Vu Van Tao, Nguyen Canh Cam. Hydraulics, Volume I, Medium and Higher Education Publishing, Hanoi, 1987.

5. Nguyen Van Hanh, On the High Resolution Numerical Methods for the Sant Venant Equations, Proc. of the International conference on the engineering mechanics today, Hanoi 1-3/1997.

6. A Le Bosse. Codes de Calcul d'ecoulement a surface libre filaire "LIDO", "SARA", et "REZO" (version 2.0). Note de validation, EDF, 1993...

7. Goutal N., Rissoan C. Note de validation du code MASCARET V5PO, EDF, 2000.

8. Nguyen Van Diep, Ngo Huy Can, Ha Ngoc Hien, Mai Dinh Trung, Nguyen Van Hanh, Nguyen Van Que, Trinh Quang Hoa, Hoang Van Lai. Modelling Technology and Red River System Flood Control, Proc. of International European-Asian Workshop Ecosystem \& Flood 2000.

9. Nguyen Van Diep, Ngo Huy Can, Hoang Van Lai, Trinh Quang Hoa, Nguyen Van Que, Nguyen Van Hanh and others. Numerical simulation of flood in the Red-Thai binh river system, Proc: of National Conference on Fluid Mechanics and New Technology, 2001 (in vietnamese).

10. The final report of research project "Construction of numerical simulation technique for proposal, evaluation, and operation of flood protection measures in the Red-Thai Binh river delta". Institute of Mechanics. 2001.

Received June 27, 2002

\section{VỀ CÁC MÔ HİNH THƯY LỰC LIÊN KẾT MỘT VẢ GIẢ HAI CHIỀU CHO MẠGG SÔNG PHỨC TẠP - KIỂM ĐỊNH VÀ ỨNG DỤNG}

Bài báo này trình bày một cách tiếp cận xây dựng mô hình thủy lực một và giá hai chiều cho mạng sông phức tạp, bao gồm cá các công trình thủy lực. Mô hình dựa trên lời giải số của phương trình Saint-Venant cho các đoạn sông đơn, phương trình liên tục cho các ô chứa, phương trình cho các điều kiện liên kết các điểm phân lưu và hợp lưu, phương trình cho các công trình thủy lực giữa các đoạn sông và các ô chứa. Các mặt cắt được mô phơng dưới dạng dòng cháy trong lòng và trên bãi nhằm mô phơng dòng chảy phù hợp hơn. Chương trình đã được xây dựng, được kiểm tra bằng các bài toán mẫu khác nhau do các Viện Thủy lực lớn của châu Ẩu xây dựng và sau đó được áp dụng để xây dựng mô hình thưy lực cho mạng sông Hồng phức tạp. 